\title{
PENINGKATAN KEMAMPUAN BERHITUNG ANAK KELOMPOK B USIA 5-6 TAHUN MELALUI PERMAINAN TRADISIONAL BATUANG ANGKO
}

\author{
ADRITA \\ Guru Taman Kanak-kanak Kuncup Mawar Balai Gurah Ampek Angkek \\ Sumatera barat \\ e-mail : addrita297@gmail.com
}

\begin{abstract}
Abstrak
Penelitian ini dilakukan untuk mendeskripsikan kemampuan berhitung melalui permainan tradisional batuang angko anak Kelompok B usia 5-6 tahun. Penelitian di TK Kuncup Mawar menggunakan Metode Penelitian Tindakan Kelas. Prosedur penelitian yang dilaksanakan terdiri dari perencanaan, tindakan, observasi dan juga refleksi. Teknik pengumpulan data yang digunakan dalam penelitian ini adalah observasi dan dokumentasi. Teknik analisis data yang di gunakan berupa analisis data kualitatif dan juga analisis data kuantitatif. Pada pelaksanaan pratindakan dilakukan untuk mengukur kemampuan berhitung anak diperoleh persentase sebesar $53.3 \%$. Kemudian siklus I terjadi peningkatan sebesar $65.45 \%$ dan pada siklus II dilaksanakannya tindakan diperoleh peningkatan sebesar $85.84 \%$. Dari hasil yang didapat terlihat permainan tradisional batuang angko mampu meningkatkan kemampuan berhitung anak. Dalam aspek anak mampu menyebutkan lambang bilangan 1-20, anak mampu membilang, anak mampu mengenal lambang bilangan, dan anak mampu mencocokkan bilangan dengan lambang bilangan.
\end{abstract}

Kata Kunci: Batuang Angko, Permainan Tradisional, Berhitung

\section{PENDAHULUAN}

Pendidikan anak usia dini sangat penting karena masa usia dini merupakan periode emas (golden age) bagi perkembangan anak untuk memperoleh proses pendidikan. Sejalan dengan diharapkan perhatian dan kesadaran terhadap pendidikan anak usia dini yang semakin baik membawa dampak positif bagi perkembangan anak selanjutnya. Melalui PAUD, diharapkan anak dapat mengembangkan seluruh potensi yang dimilikinya yang meliputi pengembangan moral dan nilai-nilai agama, fisik, sosial, emosional, bahasa, seni, menguasai sejumlah pengetahuan dan keterampilan sesuai dengan perkembangan, serta memiliki motivasi dan sikap, belajar untuk berkreasi (Susanto, 2017:16). Salah satu aspek yang perlu dikembangkan bagi Anak Usia Dini adalah aspek kognitif yang berhubungan dengan kemampuan berhitung awal bagi anak. Department of Education and Skills (2011) bahwa kegiatan berhitung tidak terbatas pada kemampuan menggunakan angka, menambah, mengurangi, mengalikan, dan membagi. Berhitung mencakup kemampuan untuk menggunakan pemahaman dan keterampilan matematika untuk memecahkan masalah dan memenuhi tuntutan kehidupan sehari-hari dalam pengaturan sosial yang kompleks. Untuk memiliki kemampuan ini, seorang remaja harus mampu berpikir dan berkomunikasi secara kuantitatif, memahami data, memiliki kesadaran spasial, 
memahami pola dan urutan, dan mengenali situasi di mana penalaran matematis dapat diterapkan untuk memecahkan masalah.

Kemampuan berhitung adalah kemampuan yang dimiliki setiap anak untuk dikembangkan. Kemampuan ini dimulai dari yang terdekat lingkungan yang dapat meningkat ke tingkat pemahaman tentang jumlah, yang terkait dengan penambahan dan pengurangan (Susanto, 2011: 98). Jadi, berdasarkan studi keterampilan berhitung. Dengan demikian, penelitian berfokus pada aritmatika tentang konsep penjumlahan. Ditambahkan Smith (2009) bahwa: "Counting is universal skill that appears to be asily acquired at an early age". Anak usia dini memiliki banyak potensi yang harus dikembangkan dengan optimal agar mereka nantinya memiliki keberhasilan ketika mereka dewasa termasuk pengembangan aspek kognitif yang berhubungan dalam hal kemampuan berhitung awal. Sejalan dengan apa yang disampaikan oleh Dodge (2002) bahwa berhitung adalah: "Counting is one of the earliest number concept to emerge". Berhitung merupakan salah satu dari konsep angka yang paling mudah untuk dimunculkan. Kegiatan berhitung anak usia dini tersebut bisa di lakukan melalui kegiatan bermain yang menyenangkan, Kemampuan berhitung merupakan bagian keterampilan yang diperlukan dalam kehidupan sehari-hari. Berhitung adalah ilmu pasti yang tidak bisa diterka ataupun ditebak, selain itu berhitung merupakan salah satu ilmu yang dapat digunakan dalam kehidupan sehari-hari, mulai dari anak-anak, orang dewasa, sampai orang tua (Kuraesin, 2013: 1).

Dalam mengembangkan semua aspek anak usia dini dilakukan dengan kegiatan bermain, fadlillah (2017:7) mengatakan bahwa bermain merupakan upaya untuk memperoleh kegembiraan kesenangan dan kepuasaan jiwa dari aktivitas yang dilakukan, baik bermain menggunakan alat maupun tidak. Tujuan utama adalah memberikan kegembiraan kepada anak dengan permainan yang dilakukan tanpa mengutamakan hasil akhir yang diperoleh. Ditambahkan Mukhtar Latif (2013) bermain merupakan aktivitas langsung dan spontan anak dalam berinteraksi dengan orang lain, benda-benda sekitarnya, dilakukan dengan senang (gembira) dorongan sendiri tanpa ada paksaan pihak lain, menggunakan daya imajinatif (khayal) menggunakan seluruh anggota tubuhnya. Dari beberapa penjelasan diatas dapat disimpulkan bahwa bermain adalah kegiatan yang dilakukan secara spontan, menyenangkan tanpa mengedepankan hasil akhir.

Melalui kegiatan bermain mampu memenuhi kebutuhan anak untuk secara aktif terlibat dengan lingkungan, bermain dan bekerja dalam menghasilkan suatu karya, serta untuk memenuhi tugas-tugas perkembangan kognitif lainnya. Selama kegiatan bermain, anak menerima pengalaman baru, memanipulasi bahan dan alat, berinteraksi dengan orang lain, dan merasakan dunia mereka. Bermain menyediakan kerangka kerja untuk anak untuk mengembangkan pemahaman Yuliani Nurani Sujiono (2006:63) tentang diri mereka sendiri, orang lain, dan lingkungan. Bermain adalah awalan dari semua fungsi kognitif selanjutnya, oleh karenanya bermain sangat diperlukan dalam kehidupan anak-anak.

Pelaksanaan kegiatan bermain bagi anak usia dini dapat dilakukan dengan memodifikasi permainan yang sering di temui oleh anak, kegiatan 
bermain yang sering ditemui anak-anak. Modifikasi permainan didasarkan pada teori belajar konstruktivisme dimana anak harus aktif belajar dalam membangun pengetahuannya sendiri (Lapono, et al., 2008). Dengan menggunakan media kartu angka dan kartu bergambar, anak dapat secara mandiri menjawab pertanyaan yang tertulis pada kartu tersebut. Selain itu, penggunaan kartu angka menjadi kunci agar anak dapat memilih memasuki gerbang yang diinginkan sebagai stimulus bagi anak dan membuat mereka lebih disiplin. Hal ini terkait dengan teori perilaku belajar yang mempelajari perilaku manusia. Teori tersebut menjelaskan bahwa, perilaku manusia terjadi melalui suatu stimulus yang didasarkan pada stimulus baik berupa reward maupun aturan yang menyebabkan terjadinya hubungan perilaku atau respon reaktif (Fahyuni \& Istikomah, 2016:26)

Begitu juga dalam meningkatkan kemampuan berhitung anak usia dini dapat dilakukan dengan kegiatan bermain dengan menggunakan media yang mudah ditemui di lingkungan sekitar anak, sepertipermainan tradisional yang sudah mulai hilang digantikan oleh media bermain yang lebih modern. Euis Kurniati (2017:1) mengatakan bahwa permainan tradisional merupakan permainan yang tumbuh dan berkembang di daerah tertentu dengan sarat dengan nilai-nilai budaya dan tatanan nilai kehidupan masyarakat dan di ajarkan turun temurun dari satu generasi kegenerasi berikutnya. Permainan yang bertujuan meningkatkan kemampuan berhitung pada anak usia 5-6 tahun, salah satunya adalah dengan permainan Batuang Angko.

Berdasarkan hasil observasi di TK Kuncup Mawar Balai Gurah di temukan dalam proses kegiatan pembelajaran, peserta didik kurang mampu dalam menghitung maupun mengenal angka dengan baik, anak belum mampu dalam membedakan angka 6 dan 9, anak belum mampu dalam mencocokkan angka sesuai dengan bilangan secara urut dan benar.

Perhatian guru dan metode yang tepat dalam mengajarkan anak-anak sangat diutamakan. Karena keberhasilan seorang anak dalam belajar seperti berhitung, tergantung dari perhatian dan metodepembelajaran yang sesuai. Selain belum mampu berhitung secara urut dan benar, anak-anak juga belum mampu membedakan angka-angka yang dipilih dalam mengaturnya. metode yang kurang tepat, guru yang tidak terlalu kreatif dalam menyajikan proses kegiatan pembelajaran yang menarik juga menjadi factor yang mempengaruhi perkembangan kemampuan berhitung anak tidak berjalan dengan optimal.

Dengan fenomena yang telah di uraikan diatas, penulis menemukan bagaimana cara menyajikan proses kegiatan pembelajaran yang menyenangkan untuk peserta didik melalui kegiatan bermain dengan menggunakan alat bermain tradisional yang sering ditemui oleh peserta didik sehingga penyampaian tujuan dari proses kegiatan pembelajaran dalam meningkatkan kemampuan berhitung lebih optimal. Seperti yang dijelaskan dalam Peraturan Menteri Pendidikan dan Kebudayaan Republik Indonesia, Undang-Undang (Nomor 137 Tahun 2014:26 Tentang Standar Nasional Pendidikan Anak Usia Dini. Anak dikatakan mampu berhitung ketika menyebutkan bilangan 1-20, memasang lambang bilangan 1-20, mencocokkan bilangan dengan lambang bilangan 1-20. Dari pernyataan tersebut 
peneliti memilih kegiatan bermain batuang angko untuk meningkatkan kemampuan berhitung anak.

\section{METODE}

Penelitian ini menggunakan metode Penelitian Tindakan Kelas Model penelitian yang digunakan adalah model Kurt Lewis dalam Fitrianti (2016:22) terdiri dari beberapa kegiatan pelaksanaannya. Kegiatan penelitian meliputi: perencanaan (planing), pelaksanaan (action), pengumpulan data (observing), dan menganalisis data untuk memutuskan sejauh mana kelemahan tindakan tersebut (reflecting).

Penelitian dilakukan pada anak kelompok B usia 5-6 tahun di TK kuncup Mawar Balai Gurah dengan jumlah anak yang diteliti sebanyak 15 orang, 6 orang anak perempuan dan 9 orang anak laki-laki. Teknik pengumpulan data yang dilaksanakan dalam penelitian ini adalah dengan observasi dan juga dengan dokumentasi.

Kriteria keberhasilan dalam penelitian ini adalah penelitan yang dilakukan dikatakan berhasil jika Kegiatan pembelajaran yang dilaksanakan dinyatakan berhasil apabila terjadi perubahan yaitu berupa peningkatan dalam kemampuan berhitung anak dengan batuang angko menunjukkan rata-rata yang mencapai persentase $76 \%$ dikatakan kemampuan berhitung sudah berkembang sangat baik. Keberhasilan tersebut dihitung melalui indikator perkembangan kemampuan berhitung anak yang dilakukan pengambilan datanya melalui observasi oleh peneliti dan kolaborator.

\section{HASIL PEMBAHASAN}

Penelitian tindakan ini dilakukan terfokus untuk anak kelompok B dengan usia 5-6 tahun pada pengembangan aspek kognitif kusus pada kemampuan berhitung yang pelaksanaannya di sesuai dengan tema dan sub tema. Indikator pertama adalah anak mampu menyebutkan lambang bilangan 1-20, Indikator kedua anak mampu membilang, Indikator ketiga anak mampu mengenal lambang bilangan, dan indikator keempat anak mampu mencocokkan bilangan dengan lambang bilangan.

Hasil dari penelitian tindakan yang dilakukan dalam kegiatan peningkatan kemampuan berhitung anak melalui batuang angko: kesepakatan sebelum dilakukan tindakan dengan kolaborator persentase keberhasilan penelitian yang ditetapkan adalah sebesar $75 \%$. Dilihat dari pra tindakan, siklus pertama dan kedua terjadi peningkatan pada kemampuan berhitung anak melalui batuang angko, dengan peningkatan tersebut maka batuang angko berhasil dalam meningkatkan kemampuan berhitung anak kelompok B usia 5-6 tahun di TK Kuncup Mawar Balai Gurah.

Terlihat dari hasil penelitian pada penelitian pra-tindakan pesentase kemampuan berhitung anak menggunakan batuang angko adalah 53,5\% kemudian meningkat setelah dilakukannya penelitian pada siklus 1 dengan hasil pesentase tindakan sebesar $65,45 \%$ kemudian pada siklus 2 kemampuan berhitung anak menggunakan batuang angko meningkat sebesar $85,82 \%$. 
Dengan hasil persentase yang di peroleh pada siklus II sebesar $85.82 \%$ maka sudah mencapai standar penilaian yang telah ditentukan yaitu $80 \%$.

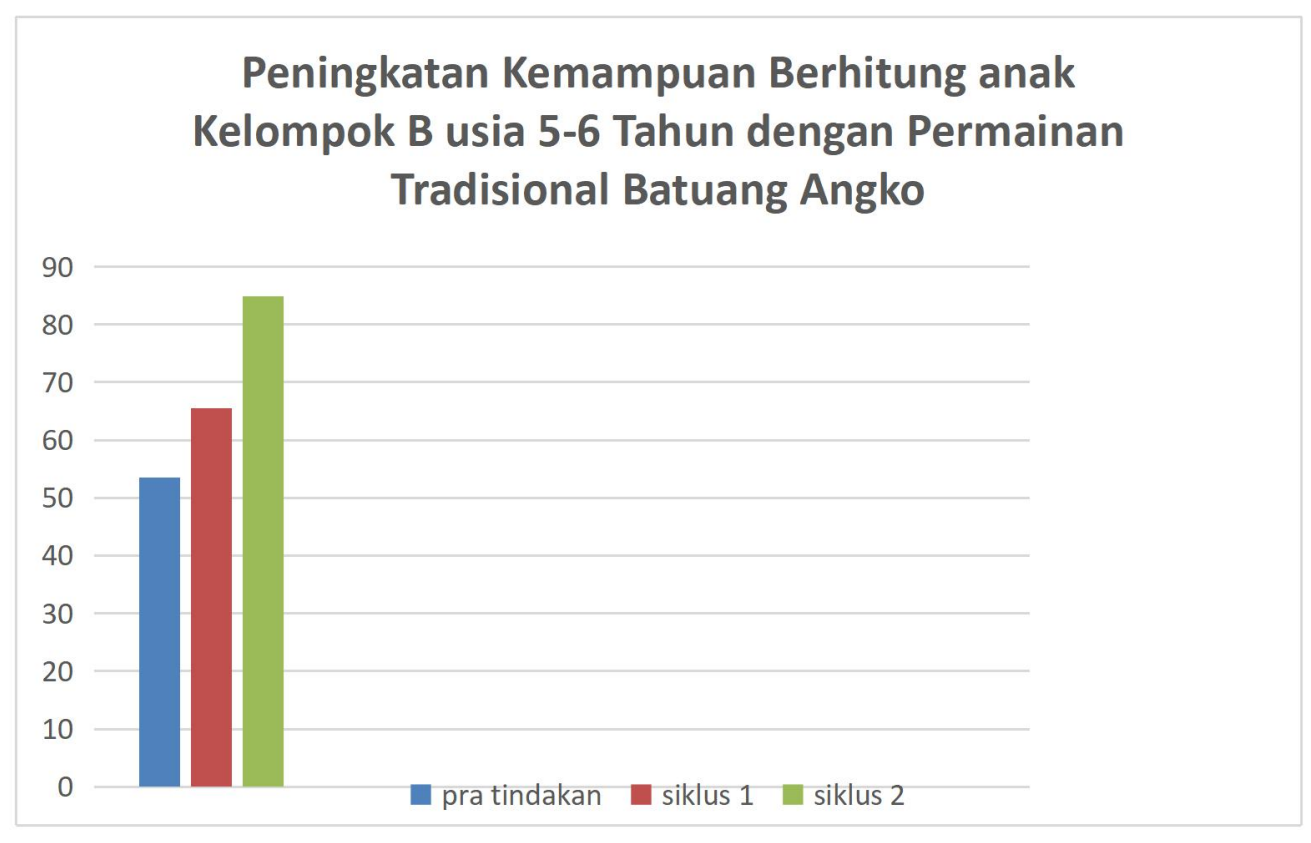

Dari hasil yang terlihat mulai dari pra-tindakan yang dilakukan kemudian tindakan Siklus I dan Siklus II membawa dampak yang sangat baik terhadap kemampuan berhitung anak di TK Kuncup Mawar, proses kegiatan pembelajaran yang dilakukan dengan kegiatan bermain akan memperoleh hasil yang optimal dibandingkan dengan proses pembelajaran yang focus kepada hasil yang ingin dicapai tanpa proses yang bertahap. Kegiatan bermain akan menyenangkan bagi anak, anak tidak merasa terpaksa, anak antusias dengan kegiatan yang disajikan sehingga anak merasa mereka sedangkan melakukan kegiatan bermain tanpa memikirkan hasil akhir yang harus mereka selesaikan (ozdogan, 2011). Penggunaan permainan tradisional sebagai salah satu media dalam proses kegiatan pembelajaran merupakan langkah dalam menciptakan proses kegiatan pembelajaran yang bermakna Bersama anak karena permainan tradisional adalah permainan yang mudah dijumpai anak di lingkungan sekitar dan juga mengajarkan anak untuk mencintai, memiliki rasa bangga dengan daerahnya (Keen Achroni:2012:71).

Anak-anak terutama Anak usia dini akan lebih tertarik melakukan proses kegiatan belajar melalui permainan dibandingkan dengan pemberian lembar kerja oleh guru. Melalui permainan anak akan lebih tertarik untuk belajar karena bermain merupakan kegiatan yang menyenangkan bagi mereka. Didukung oleh penelitian yang dilakukan oleh Skwarchuk et al. (2014) menjelaskan bahwa konsep berhitung yang dilakukan melalui permainan lebih mudah dipahami anak daripada melalui kegiatan pengayaan umum atau lembar kerja. Selain itu, Dieleman dan Huisingh (2006), juga menyimpulkan bahwa game terbukti bermanfaat sebagai komponen dalam proses pembelajaran. 


\section{KESIMPULAN}

Berdasarkan penelitian dan pembahasan yang telah diuraikan, hasil yang diperoleh dengan analisis data mulai dari pra-tindakan Tingkat Capaian Perkembangan TCP yang diperoleh adalah 53,5\% kemudian meningkat setelah dilakukannya penelitian pada siklus 1 dengan hasil TCP sebesar $65,45 \%$ kemudian pada siklus 2 TCP yang diperoleh sebesar $85,82 \%$. Berada pada Berkembang Sangat Baik BSB 10 dari 15 orang anak mampu menyelesaikan kegiatan bermain dengan menggunakan batuang angko untuk meningkatkan kemampuan berhitungnya. Dalam aspek anak mampu menyebutkan lambang bilangan 1-20, anak mampu membilang, anak mampu mengenal lambang bilangan, dan anak mampu mencocokkan bilangan dengan lambang bilangan. Dengan demikian pemberian tindakan penggunaan permainan tradisional batuang angko dapat meningkatkan kemampuan berhitung anak kelompok $B$ usia 5-6 tahun di TK kuncup Mawar Balai Gurah.

\section{DAFTAR PUSTAKA}

Keen Achroni. 2012. Mengoptimalkan Tumbuh Kembang Anak Melalui Permainan Tradi-sional. Jogjakarta: Javalitera

Dieleman, Hans dan Huisingh, Don. Permainan untuk belajar dan mengajar tentang pembangunan berkelanjutan: mengeksplorasi relevansi permainan dan pembelajaran berdasarkan pengalaman untuk keberlanjutan. Journal of Cleaner Production. Vol. 14, hlm. 837-847, 2006.

Dodge, D.T. 2002. The creative curriculum for preschool. USA: Teaching Strategies.

The Department of Education and Skills wishes to thank the schools below for permission to use photographs: Schull Community College, Colla Road, Schull, Co. CorkWhitechurch National School, Whitechurch Road, Dublin 16

Smith, S.S. 2009. Early childhood mathematics. USA: Person Education

Susanto, Ahmad. 2011. Perkembangan Anak Usia Dini: Pengantar Dalam Berbagai Aspeknya. Jakarta: Kencana Prenada Media Group.

Skwarchuk, Sheri-Lynn, et.al. Kegiatan belajar di rumah secara formal dan informal dalam kaitannya dengan perkembangan usia dini anak berhitung dan keterampilan melek huruf: Pengembangan model berhitung rumah. Journal of Experimental Child Psychology. Vol. 121, hlm. 63-84, 2014.

Peraturan Menteri Pendidikan dan Kebudayaan Republik Indonesia No.137 Tahun 2014. Jakarta: Direktorat PAUD.

Fadlillah. 2017. Bermain dan Permainan. Jakarta: Kencana

Fahyuni, Eni Fariyatul \& Istikomah. 2016. Psikologi Belajar dan Mengajar. Sidoarjo: Nizamia Learning Center.

Kuraesin, lis. 2013. Usia Pra Sekolah Melalui Kartu Angka di Taman KanakKanak TK Ketilang Sukahurip Kecamatan Cihaurbeuti Kabupaten Ciamis. Universitas Terbuka: Tasikmalaya.

Kurniati, E. 2016. Permainan tradisional dan perannya dalam mengembangkan keterampilan sosial anak. Jakarta: Prenadamedia Group.

Latif Mukhtar, dkk. (2013). Orientasi Baru Pendidikan Anak Usia Dini. 
Kencana. LN, Y. S. 2016. Psikologi Perkembangan Anak \& Remaja. Rosdakarya. Lapono, N, et.al. 2008. Belajar dan Pembelajaran. Jakarta: Dirjen Pendidikan Tinggi Depdiknas.

Ozdogan,E. 2011. Play, Mathematic and mathematical play in early childhood education. Procedia- Sosial and Behavioral Science Sciences, 15, 3118-3120. https://doi.org/10.1016/j.sbspro.2011.04.256 